\title{
EFFECTS OF CROPPING PATTERN ON CARBON SEQUESTRATION AND AGGREGATE STABILITY OF SOIL IN LONG TERM AGRICULTURAL FIELDS IN KHULNA, BANGLADESH
}

\author{
Md Tareq Bin Salam*, Md Tipu Sultan, Mehjabin Hossain \\ and Must Alima Rahman ${ }^{1}$
}

\author{
Soil, Water and Environment Discipline, Khulna University, Khulna-9208, Bangladesh
}

Keywords: Soil carbon sequestration, Soil organic carbon, Aggregate stability, Carbon input, Carbon stock

\begin{abstract}
Effects of cropping pattern on soil carbon sequestration and their aggregate stability in long term agricultural fields was investigated in 2018. Four cropping patterns were selected that have been cultivated for last ten years. Results showed that Soil organic carbon (SOC) value was improved for vegetable field from 4.06 to $9.11 \mathrm{~g} / \mathrm{kg}$ and carbon stock $(20.14 \mathrm{Mg} \mathrm{C} \mathrm{ha/yr)} \mathrm{as} \mathrm{well} \mathrm{as} \mathrm{soil} \mathrm{carbon} \mathrm{sequestration} \mathrm{rate} \mathrm{was} \mathrm{the}$ highest in vegetable field (1.12 Mg C ha/yr). The logarithmic relationship between the $\mathrm{C}$ input and $\mathrm{C}$ sequestration rate showed the strong correlation $(r=0.72, p<0.05)$. In terms of aggregate stability, vegetable field put the best result $(0.41 \mathrm{~mm})(\mathrm{p}>0.05)$. The straight-line relation between aggregate stability and Cstock established that they are strongly correlated $(\mathrm{r}=0.81, \mathrm{p}<0.05)$. Finally, results indicated that Vegetable-Vegetable-Vegetable cropping pattern was the best soil carbon sequester along with the best aggregate stability.
\end{abstract}

\section{Introduction}

Bangladesh is a land of agriculture. Due to lower income capacity of farmers (per capita GDP $\$ 1610$, fy $2016-17$ by $\mathrm{BBS}$ ) as well as higher illiteracy rate, agricultural soils are treated indiscriminately through intensive tillage and nonscientific cropping pattern thus accelerated loss of soil organic matter. The global temperature has already increased $1.3^{\circ} \mathrm{C}$ over past decade and is projected to enhance 3.2 to $7.2^{\circ} \mathrm{C}$ over the $21^{\text {st }}$ century (IPCC 2007). Agriculture has a potential role in global climate change. The incremental $\mathrm{C}$ sequestration not only increases soil fertility but also mitigates atmospheric $\mathrm{CO}_{2}$ (Blanco-Canqui and Lal 2004). The $\mathrm{C}$ input of crop land is estimated from the incorporation of crop residues along with crop yield or aboveground biomass (Li et al. 2010, Zhang et al. 2012). Normally, high C input leads high C sequestration and the relationship is linear (Kong et al. 2005, Li et al. 2010, Ghosh et al. 2012), whereas other researchers found a logarithmic correlation (West and Six 2007). Soil organic matter (SOM) controls the buffering capacity along with microbial biodiversity water retention and structural stabilization of soils that regulates soil properties (Gaida et al. 2013). Determination of soil aggregate stability has an important effect on $\mathrm{C}$ supplies, and soil organic carbon (SOC) (BlancoCanqui and Lal 2004). Khulna is situated at south western part of the Bangladesh. Most of the lands are being cultivated with conventional farming. Intensive cropping patterns are being practiced year after year due to ignorance of adopting modern tillage technology. Hence, the present study was conducted to determine (i) the response of SOC stock to C input under different cropping pattern, (ii) $\mathrm{C}$ sequestration efficiency in different cropping pattern and (iii) the response of aggregate stability with increasing SOC stock in different cropping pattern. The findings will be helpful to understand about the role of carbon sequestration in agriculture towards climate change.

*Author for correspondence: <tareqss@ swe.ku.ac.bd>. ${ }^{1}$ Agricultural Chemistry Department, Sher-e-Bangla Agricultural University, Dhaka-1207, Bangladesh. 


\section{Materials and Methods}

A field experiment was conducted in 2018 at four different cropping pattern long term fields in 3 different villages of Dumuria Upazila (sub-district), Khulna, Bangladesh. The Dumuria Upazila is located at $22^{\circ} 39^{\prime}$ and $22^{\circ} 56^{\prime}$ north altitude and $89^{\circ} 15^{\prime}$ and $89^{\circ} 32^{\circ}$ east longitude, surrounded by Jashore and Satkhira districts (SRDI 2008). Traditionally, rice, wheat and vegetables are the main crops that are being cultivated by the farmers. In this experiment, 4 types of cropping patterns were followed which have a monotonous soil texture (Table 1). The soil samples were taken by shovel from the plough horizon $(0-15 \mathrm{~cm})$ from different parts of the respective cropping pattern field at early and end of the each cropping seasons and replicated 3 times. All core samples were randomly taken from individual cropping pattern field to determine the soil bulk density. After preparing soil samples, aggregate stability was measured by wet sieving method as proposed by Le Bissonnais (1996). Soil texture was determined by pipette method. SOC was determined by oxidation with potassium dichromate. Initial SOC data were taken from Fertilizer recommendation guide of Dumuria Upazila (SRDI 2008). So, the duration between the cropping field conditions was 10 years.

Table 1.Location, cropping patterns, coding and soil textural class in the studied area.

\begin{tabular}{|c|c|c|c|c|}
\hline $\begin{array}{l}\text { Sampling } \\
\text { area }\end{array}$ & Location (GPS) & $\begin{array}{c}\text { Cropping pattern } \\
\text { (Rabi - Kharif } 1 \text { - Kharif 2) }\end{array}$ & $\begin{array}{l}\text { Cropping pattern } \\
\text { Code }\end{array}$ & Soil Texture \\
\hline Chechuria & $89^{\circ} 29^{\prime} \mathrm{E}, 22^{\circ} 47^{\prime} \mathrm{N}$ & Rice-Fallow-Rice & R-F-R & \\
\hline Chechuria & $89^{\circ} 27^{\prime} \mathrm{E}, 22^{\circ} 46^{\prime} \mathrm{N}$ & Rice-Rice-Vegetable & R-R-V & \\
\hline Boruna & $89^{\circ} 21^{\prime} \mathrm{E}, 22^{\circ} 39^{\prime} \mathrm{N}$ & Rice-Wheat-Fallow & R-W-F & Silty clay loam \\
\hline Chingra & $89^{\circ} 17^{\prime} \mathrm{E}, 22^{\circ} 52 \mathrm{~N}$ & $\begin{array}{c}\text { Vegetable-Vegetable- } \\
\text { Vegetable }\end{array}$ & V-V-V & \\
\hline
\end{tabular}

Annual organic $\mathrm{C}$ input $\left(\mathrm{C}_{\text {input }}, \mathrm{Mg}\right.$ ha-1yr-1) was estimated from stubble and below ground roots which were incorporated into the topsoil $\left(\mathrm{C}_{\text {stubble+roots }}\right)$, and from organic manure $\left(\mathrm{C}_{\text {manure }}\right)$ using the following equation (Yan et al. 2013):

$$
\begin{aligned}
& \mathrm{C}_{\text {input }}=\mathrm{C}_{\text {stubble }}+\text { roots } \\
& \mathrm{C}_{\text {stubble }}+\mathrm{C}_{\text {manur }} \\
& \mathrm{C}_{\text {manure }}=\text { Biomass }_{\text {manure }} \times \mathrm{BC}_{\text {manure }}
\end{aligned}
$$

Where $\chi$ is the ratio of stubble plus roots to yield. $\mathrm{OC}_{\text {stubble + roots }}$ is the organic $\mathrm{C}$ concentration of stubble and roots. $\mathrm{OC}_{\text {manure }}$ is the organic $\mathrm{C}$ concentration of manure, which is the dry biomass of organic amendments applied $\left(\mathrm{Mg} \mathrm{ha}^{-1} \mathrm{yr}^{-1}\right)$.

The $\mathrm{C}$ stock $\left(\mathrm{Mgha}^{-1}\right)$ in the plough horizon was calculated by the following equation (Yan et al. 2013):

$$
\mathrm{C}_{\text {stock }}=\mathrm{SOC} \times \rho \times \mathrm{H} \times 10
$$

Where $\rho$ is the soil bulk density $\left(\mathrm{gcm}^{-3}\right)$, and $\mathrm{H}$ is the depth of the plough horizon which is $0.15 \mathrm{~m}$ for sampling soils. The stubble and roots after harvest were measured from an area of 0.2 $\mathrm{m} \times 0.2 \mathrm{~m}$ to a depth of $0.3 \mathrm{~m}$ with three replications. The roots were collected, oven-dried at $65^{\circ} \mathrm{C}$, and weighed.

The $\mathrm{C}$ sequestration rate $(\mathrm{Mg} \mathrm{ha} / \mathrm{yr})$ in the plough horizon during the period of the experiment was calculated using the following equation (Yan et al. 2013):

$$
\mathrm{C} \text { sequestration rate }=\left(\mathrm{SOC}_{\text {curent }}-\mathrm{SOC}_{\text {initial }}\right) \times \rho \times \mathrm{H} \times \frac{10}{T} \quad \text { (5) }
$$

Where $\mathrm{SOC}_{\text {current }}$ and $\mathrm{SOC}_{\text {initial }}$ are the $\mathrm{SOC}$ in the current year and the initial year $(\mathrm{g} / \mathrm{kg})$. The collected data were analyzed by using Microsoft Excell-07 and analysis of variance technique 
(ANOVA) was determined with the help of computer package programmed SPSS-16.0 and the least significant difference (LSD at $\mathrm{p}<0.05)$ test was applied to assess the differences among the means.

\section{Results and Discussion}

The initial soil organic carbon (SOC) varied from 4.06 to $8.70 \mathrm{~g} / \mathrm{kg}$ and significantly differed from each other ( $\mathrm{p}<0.05$ ) (Fig. 1). SOC was higher in R-W-F cropping pattern and lowest in V$\mathrm{V}-\mathrm{V}$ field. The current SOC varied from 3.31 to $9.11 \mathrm{~g} / \mathrm{kg}$. Except R-W-F, other cropping patterns revealed significant difference in SOC from each other $(\mathrm{p}<0.05)$. The values of SOC, Carbon input, Bulk Density, Carbon stock and Carbon sequestration are presented in Table 2. C-input rate was higher in V-V-V field where as lowest was found in R-F-R field and they were significantly differed with each other except R-W-F ( $<$ < 0.05). Bulk density was higher in R-W-F and significant with each other $(\mathrm{p}>0.05)$. Due to higher $\mathrm{C}$-input, $\mathrm{V}-\mathrm{V}-\mathrm{V}$ cropping pattern also stocked the higher amount of carbon. Except R-F-R, all other soil carbon indicators were significant ( $\mathrm{p}$ 0.05). Fig. 2 displays a logarithmic relationship between the $\mathrm{C}$ input rate and the $\mathrm{C}$

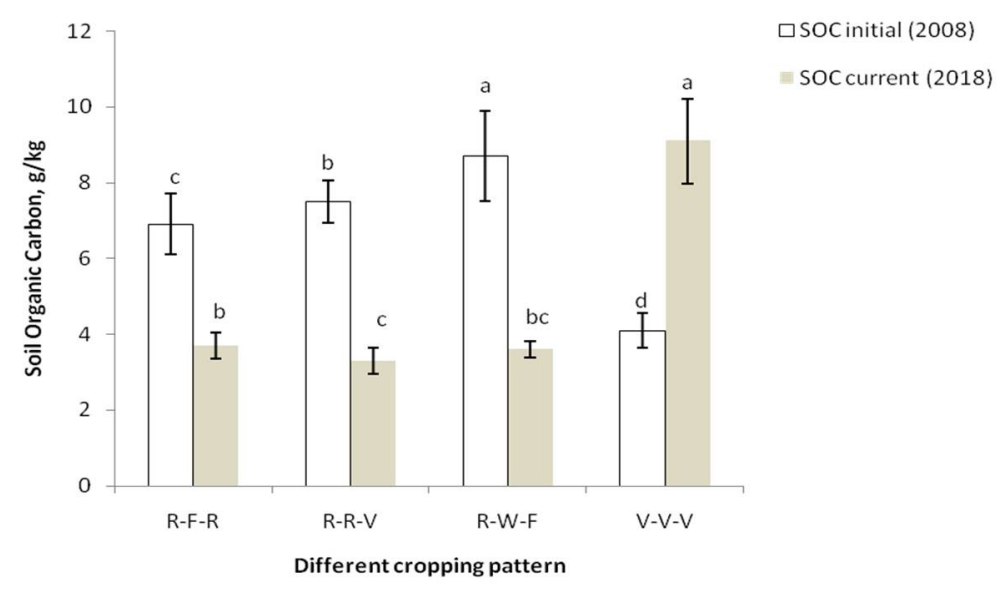

Fig. 1.Soil organic carbon (SOC) in different cropping pattern $(\mathrm{p}<0.05)$.

Table 2.SOC, C-input and C-sequestration status in soils of different cropping pattern.

\begin{tabular}{lcccccc}
\hline $\begin{array}{l}\text { Cropping } \\
\text { Pattern }\end{array}$ & $\begin{array}{c}\text { Current } \\
\text { SOC } \\
(\mathrm{g} / \mathrm{kg})\end{array}$ & $\begin{array}{c}\text { Initial } \\
\text { SOC } \\
(\mathrm{g} / \mathrm{kg})\end{array}$ & $\begin{array}{c}\text { C-input } \\
(\mathrm{Mg} \mathrm{C} \mathrm{ha} / \mathrm{yr})\end{array}$ & $\begin{array}{c}\text { BD } \\
\left(\mathrm{g} / \mathrm{cm}^{3}\right)\end{array}$ & $\begin{array}{c}\text { C-stock } \\
(\mathrm{Mg} \mathrm{C} \mathrm{ha} / \mathrm{yr})\end{array}$ & $\begin{array}{c}\text { C-sequestration } \\
(\mathrm{Mg} \mathrm{C} \mathrm{ha/yr})\end{array}$ \\
\hline R-F-R & $3.65^{\mathrm{b}}$ & $6.90^{\mathrm{c}}$ & $1.6^{\mathrm{c}}$ & $1.49^{\mathrm{b}}$ & $8.16^{\mathrm{bc}}$ & $-0.73^{\mathrm{c}}$ \\
R-R-V & $3.31^{\mathrm{b}}$ & $7.54^{\mathrm{b}}$ & $5.2^{\mathrm{b}}$ & $1.42^{\mathrm{b}}$ & $7.03^{\mathrm{c}}$ & $-0.90^{\mathrm{bc}}$ \\
R-W-F & $3.60^{\mathrm{bc}}$ & $8.70^{\mathrm{a}}$ & $2.3^{\mathrm{bc}}$ & $1.69^{\mathrm{a}}$ & $9.11^{\mathrm{b}}$ & $-1.29^{\mathrm{b}}$ \\
V-V-V & $9.11^{\mathrm{a}}$ & $4.06^{\mathrm{d}}$ & $8.3^{\mathrm{a}}$ & $1.47^{\mathrm{b}}$ & $20.14^{\mathrm{a}}$ & $1.12^{\mathrm{a}}$ \\
\hline
\end{tabular}

sequestration rate in four cropping patterns. The logarithmic relation showed that $\mathrm{C}$ sequestration rate increased with increase of $\mathrm{C}$ input and they were strongly correlated $(\mathrm{r}=0.72, \mathrm{p}<0.05)$. At a given amount of $\mathrm{C}$ input, the $\mathrm{C}$ sequestration rate was much higher in $\mathrm{V}-\mathrm{V}-\mathrm{V}$ field than other cropping pattern. Mean weight diameter varied between 0.41 to $0.31 \mathrm{~mm}$ (Fig. 3). V-V-V field showed the best aggregate stability and significant with other cropping fields $(\mathrm{p}<0.05)$. R-W-F and R-R-F cropping pattern were insignificant with each other $(p>0.05)$ but significant with other 
cropping pattern $(\mathrm{p}<0.05)$. Aggregate stability had a very significant positive correlation with the C-stock of soil ( $r=0.81, p<0.05)$ (Fig. 4). Results showed that SOC was lower in all cropping patterns except in vegetable field. This may happen due to intensive cropping as well as no use of organic fertilizer during crop period. In the view of agriculture sustainability, the combined chemical and organic fertilization is a promising practice to obtain a high and stable crop yield irrespective of climate change. The result is in agreement with other studies that application of organic manure increased yield as compared to chemical fertilizer alone (Li et al. 2010, Zhang et al. 2012). Vegetable field (V-V-V) having only organic manure showed the higher

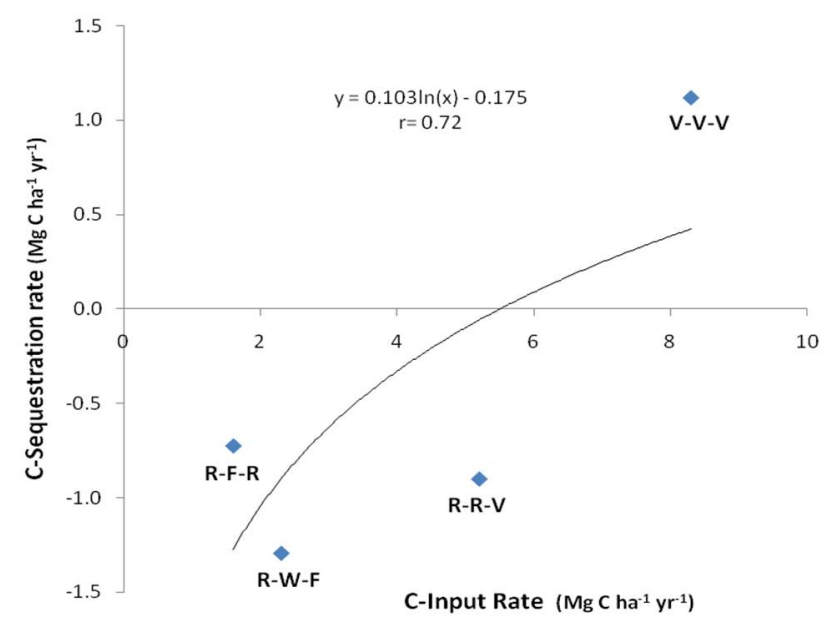

Fig. 2.Relationship between $\mathrm{C}$-input rate and C-Sequestration rate $(\mathrm{p}<0.05)$.

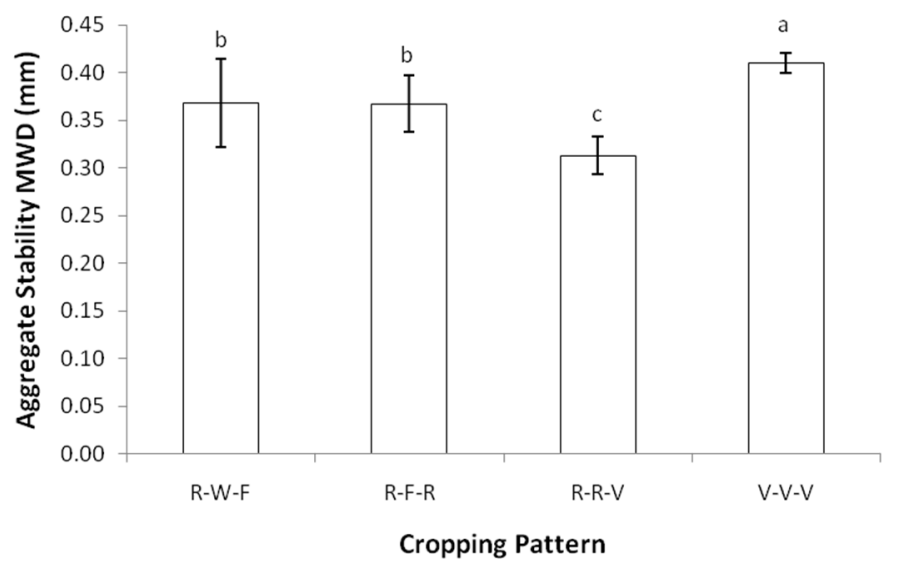

Fig. 3.Aggregate stability status in different cropping pattern $(\mathrm{p}<0.05)$.

SOC content, giving better performance under the climate change threat. C-input rate in vegetable field $(\mathrm{V}-\mathrm{V}-\mathrm{V})$ was almost 5.19 times greater than that of R-F-R cropping pattern. The source of C input in the field was stubble and roots incorporation along with direct application of organic manure. Due to higher rate of C-input in vegetable field (V-V-V); C-stock rate was almost two times greater than that of other cropping system. The logarithmic relationship between $\mathrm{C}$ input rate 
and $\mathrm{C}$ sequestration rate was negative than the R-F-R, R-R-V, and R-W-R cropping patterns due to loss of SOC over the last 10 years. The vegetable field showed the strong positive relationship $(\mathrm{r}=0.72, \mathrm{p}<0.05)$ that supports the study of many previous studies ( $\mathrm{Li}$ et al. 2010). In the experiment, vegetable field $(\mathrm{V}-\mathrm{V}-\mathrm{V})$ showed the best aggregate stability than other cropping patterns (Fig. 3). This may be due to vegetable field which received higher amount of organic fertilizer and organic residues where as other cropping system completely depends on chemical fertilizers. Application of chemical fertilizers did not improve or even decreased aggregate stability (Fig. 3), although it also decreased SOC stock (Fig. 2). Haynes and Naidu (1998) reported an adverse effect of application of chemical fertilizers on soil aggregation. They explained that the monovalent $\mathrm{NH}^{4+}$ and $\mathrm{K}^{+}$favored the dispersion of soil colloids and subsequently reduced infiltration and hydraulic conductivity. R-W-F and R-R-F showed the insignificant difference (p > 0.05 ) between them in terms of aggregate stability. This might be due to presence of fallow period for both cropping pattern. R-R-V showed the poorest aggregate stability because of intensive agriculture round the year. Soares et. al. (2005) found that intensive agriculture degrades the soil physical properties like aggregate stability, porosity, density, water infiltration rate and so on. The straight-line relation between aggregate stability and C-stock (Fig. 4) showed that they are strongly correlated $(\mathrm{r}=0.81, \mathrm{p}<0.05)$ that supports the study of Kong et. al. (2005).



Fig. 4.Relationship between aggregate stability and C-stock $(\mathrm{p}<0.05)$.

In Southwestern Bangladesh, intensive rice cultivation is widely practiced and culturally well accepted. Results showed that intensive long-term cultivation deteriorated soil organic carbon (SOC) and decline $\mathrm{C}$-stock due to poor $\mathrm{C}$-input thus reduced the rate of $\mathrm{C}$-sequestration over the last ten years. Exception was happening in vegetable field $(\mathrm{V}-\mathrm{V}-\mathrm{V})$ where SOC rate is higher due to addition of $\mathrm{C}$ externally thus improving resistance to climate change. Organic fertilization improved the $\mathrm{C}$ input and the quantity of SOC. The $\mathrm{C}$ sequestration rate was logarithmically related to the $\mathrm{C}$ input rate in all cropping pattern. Aggregate stability was higher in vegetable field due to higher organic carbon input and the relation between $\mathrm{C}$-stock and aggregate stability showed that they were strongly correlated. It can be recapitulated that $\mathrm{V}-\mathrm{V}-\mathrm{V}$ cropping pattern (vegetable field) sequesters more SOC with higher efficiency than other cropping pattern. Results indicate that securing agricultural sustainability will require organic fertilization and proper soil management practice. 


\section{Acknowledgements}

The authors are thankful to Mr. Rezaul Shaikh (Local Primary School Teacher as well as Soil Scientist) for his cooperation during the field visit and Mr. Milton Halder, Assistant Professor, Soil, Water and Environment Discipline, Khulna University, Khulna, Bangladesh for his support during the data calculation. They are also thankful to local farmers as well as all staff of Soil, Water and Environment discipline, Khulna University, Khulna, Bangladesh for their support.

\section{References}

BBS (Bangladesh Bureau of Statistics) report Fy:2016-17. http://bbs.portal.gov.bd/sites/default/files/files/ bbs.portal.gov.bd/page/a1d32f13_8553_44f1_92e6_8ff80a4ff82e/Bangladesh\%20\%20Statistics2017.pdf.

Blanco CH and Lal R 2004. Mechanisms of carbon sequestration in soil aggregates. Critical Reviews in Plant Sciences 23:481-504.

Gaida AM, Przewloka B and Gawryjolek K 2013. Changes in soil quality associated with tillage system applied. Int. Agrophysics 27:133-141.

Ghosh S, Wilson B, Ghoshal S, Senapati N and Mandal B 2012. Organic amendments influence soil quality and carbon sequestration in the Indo-Gangetic plans of India, Agricul. Ecosys. Environ. 156: 134-141.

Haynes RJ and Naidu R 1998. Influence of lime, fertilizer and manure application on soil organic matter content and soil physical conditions: a review. Nutrient Cycling in Agroecosyst. 51: 123-137.

IPCC, Climate Change 2007. The Physical Science Basis, Contribution of Working Group I to the Fourth Assessment Report of the Intergovernmental Panel on Climate Change [Solomon, S., D. Qin. and M. Manning. (eds), 2007]. http://ipcc-wg1.ucar.edu/wg1/wg1-report.html.

Kong AYY, Six J, Bryant DC, Denison RF and Kessel CV 2005. The relationship between carbon input, aggregation, and soil organic carbon stabilization in sustainable cropping systems. Soil Sci. Soc. America J. 69(4): 1078.

Le Bissonnais Y 1996. Aggregate stability and assessment of soil crustability and erodibility. I. Theory and methodology. Europ. J. Soil Sci. 47: 425-437.

Li ZP, Liu M, Wu XC, Han FX and Zhang TL 2010. Effects of long-term chemical fertilization and organic amendments on dynamics of soil organic $\mathrm{C}$ and total $\mathrm{N}$ in paddy soil derived from barren land in subtropical China. Soil and Tillage Res. 106: 268-274.

Soares JLN, Espindola, CR and Pereira WLM 2005. Physical properties of soils under intensive agricultural management, Sci. agric. (Piracicaba, Braz.). Soils and plant nutrition 62:2.

SPSS 2004.SPSS -16.0 for Windows. SPSS Inc., Chicago.

SRDI (Soil Resource Development Institute) 2008. Thana Nirdeshika Guide (Fertilizer Recommendation Guide), Ministry of Agriculture, Government of Bangladesh.

West TO and Six J 2007. Considering the influence of sequestration duration and carbon saturation on estimates of soil carbon capacity. Climatic Change 80:25-41.

Yan X, Zhou H, Zhu QH, Wang XF, Zhang YZ, Yu XC and Peng X 2013. Carbon sequestration efficiency in paddy soil and upland soil under long-term fertilization in southern China. Soil \& Tillage Research 130: $42-51$.

Zhang WJ, Xu MG, Wang XJ, Huang QH, Nie J, Li ZZ, Hwang SW and Lee KB 2012. Effects of organic amendments on soil carbon sequestration in paddy fields of subtropical China. J. Soils Sedi. 12: 457 470 . 